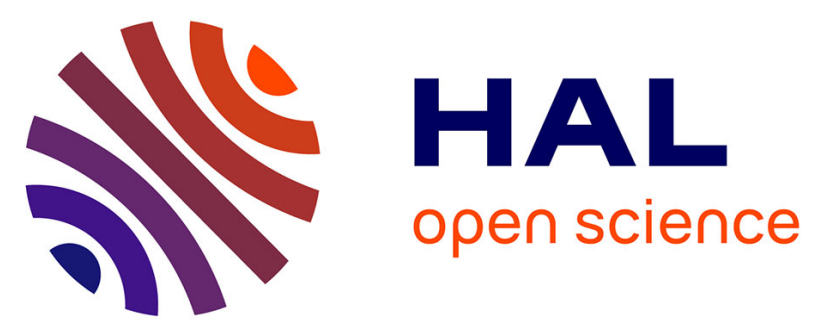

\title{
Simulation of a Doubly Fed Induction Generator used in an Autonomous Variable Speed Hydro Turbine with Maximum Power Point Tracking Control
}

Denis Ramuz, Mamadou Baïlo Camara, Henri Clergeot, Jean Kauffmann

\section{To cite this version:}

Denis Ramuz, Mamadou Baïlo Camara, Henri Clergeot, Jean Kauffmann. Simulation of a Doubly Fed Induction Generator used in an Autonomous Variable Speed Hydro Turbine with Maximum Power Point Tracking Control. 2006 12th International Power Electronics and Motion Control Conference, Aug 2006, Portoroz, France. pp.1620-1624, 10.1109/EPEPEMC.2006.4778636 . hal-03005778

\author{
HAL Id: hal-03005778 \\ https://hal.science/hal-03005778
}

Submitted on 14 Nov 2020

HAL is a multi-disciplinary open access archive for the deposit and dissemination of scientific research documents, whether they are published or not. The documents may come from teaching and research institutions in France or abroad, or from public or private research centers.
L'archive ouverte pluridisciplinaire HAL, est destinée au dépôt et à la diffusion de documents scientifiques de niveau recherche, publiés ou non, émanant des établissements d'enseignement et de recherche français ou étrangers, des laboratoires publics ou privés. 


\title{
Simulation of a Doubly Fed Induction Generator used in an Autonomous Variable Speed Hydro Turbine with Maximum Power Point Tracking Control
}

\author{
Denis Ramuz*, Mamadou Camara **, Henri Clergeot*, \\ Jean Marie Kauffmann** \\ * Groupe de Recherche sur les Energies Renouvelables (GRER) \\ IUT de Kourou - Kourou (France / French Guiana) \\ ** Laboratoire d'Electronique, Electrotechnique et Systèmes (L2ES) \\ UFC/UTBM - Belfort (France)
}

\begin{abstract}
In this paper, the authors propose an approach with problems of electricity production in isolated sites for tropical countries. Indeed, the geographical context implies often that many populations live in rural areas and are in the majority located at the edge of the rivers. The originality of this work is hybridization with a photovoltaic system via a common Direct Current bus and a maximum power point tracking control (MPPT).
\end{abstract}

\section{INTRODUCTION}

The electrification in isolated sites may be made by various systems: Power Diesel Generator, Power Water Turbine, Photovoltaic system or Wind Generation System. However, a small hydroelectric power station can ensure functions on the same principle as a wind power system: it transforms the kinetic energy of moving water into electric power. However, the speed of the wind is higher than that of water, but, as the density $(\rho)$ of water is more significant than that of the air $\left(\frac{\rho_{\text {water }}}{\rho_{\text {air }}} \approx 800\right)$, a small hydroelectric power station (S $<150 \mathrm{kVA}$ ) can produce more energy than a wind generation system with same dimensions.

The authors propose an approach by a Doubly Fed Induction Generator (DFIG) with hybridization on a DC Bus by a Photovoltaic system. Indeed, by a small hydroelectric power station with variable speed turbines, a Doubly Fed Induction Generator (DFIG) can optimize the produced power. Due to the speeds and the flows variability of tropical rivers, DFIG makes it possible to compensate the variability in acceptable proportions and guarantees a good energy quality in the network. A vector control strategy provides constant voltage and frequency, and this, in spite of the speed variations at driving shaft and of reasonable variations of power consumption; moreover it will allow hybridization with a photovoltaic system via a common Direct Current bus.
Indeed, a DFIG needs for magnetizing an auxiliary source, which feeds the windings at the rotor.

The originality of this work is to use a DC source obtained through photovoltaic cells in a small hydroelectric power station and a maximum power point tracking control (MPPT).

\section{II.HYDRAULIC SYSTEM CONFIGURATION}

Annual hydrological statements (experimental results) and over 47 years statement of the principal French Guyana rivers (IRD - French Guyana) are given the possible variations of the primary source of energy. We can note that at the different hydrological stations, the medium flows can fluctuate in an average ratio going from 1 to 3 . Thus, these experimental statements enable us to better characterize the flows of some principal rivers, and allow to make a certain choice of the unit turbine generator. Initially, the choice will be carried out by a compromise between the maximum exploitation of the flows with an output of energy conversion as highest as possible and this with the minimum of civil engineering.

The power from a hydraulic turbine is given by : $P_{(W)}=\frac{1}{2} \rho * A * V^{3} * \eta$

(1) in which

$\rho$ is the water density ( $1000 \mathrm{Kg} / \mathrm{m}^{3}$ by tropical rivers: $\left.20^{\circ} \mathrm{C}\right), \mathrm{A}$, the surface of the water turbine $\left(\mathrm{m}^{2}\right), \mathrm{V}$ the water speed $(\mathrm{m} / \mathrm{s})$ and $\eta$ the efficiency of the turbine

The advantage of the suggested turbine Banki (or Crossflow, Ossberger) is the simplicity of its construction. This turbine is appropriated for ranges of flows (Q) going from $20 \%$ to $100 \%$ and for falls varying from 1 to $200 \mathrm{~m}$. Moreover, fig. 1 shows the efficiency $(\eta)$ of such a turbine according to the flow (Q) and the used portion (compared with a Francis turbine) and figure 2 gives the efficiency according to the used portion and the specific speed. The german Banki turbine (fig. 1) has better efficiency than the american (fig.2) [1]. 


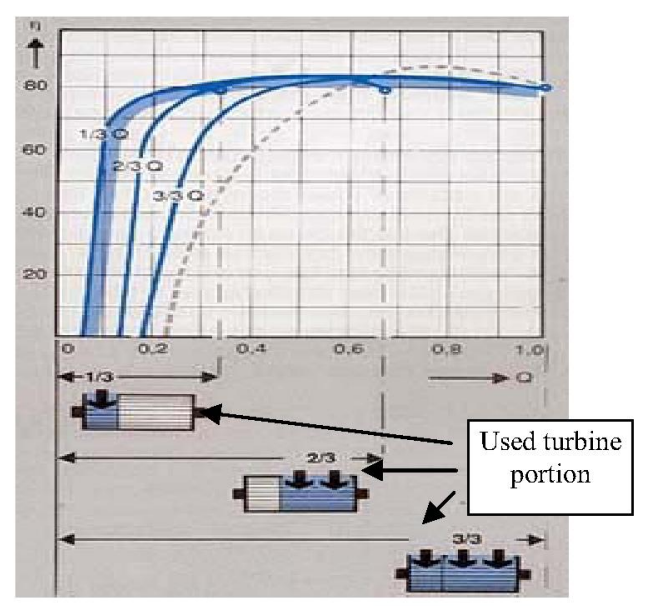

Fig. 1: Efficiency of the German Banki turbine (Ossberger) according to the used portion and the flow compared with a Francis turbine

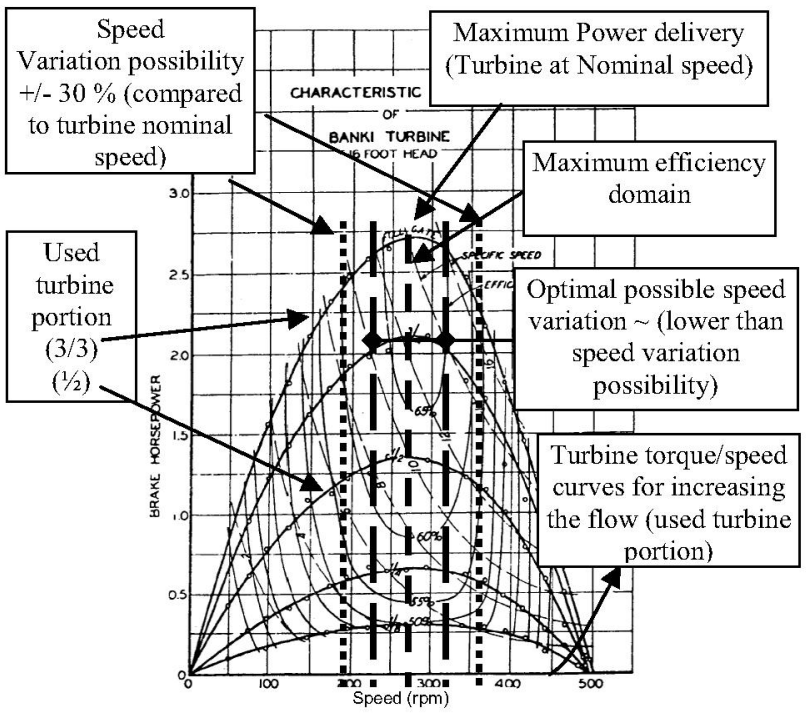

Fig.2: Horsepower and efficiency of an American Banki turbine according to the specific speed and the used portion [1]
The Banki turbine can be operated efficiently on a wider range of openings than most of turbines. Maximum efficiency occurs practically at a constant speed. The Banki turbine characteristic speed occupies a position between those for tangential and reaction turbines. It can be noticed that the power characteristic has a maximum point to be extracted from nature, which may be different from maximum efficiency. The speed at which the operating point reaches maximum generated power is the most important consideration because if the primary energy is not used at the instant it is available from nature, it will be gone. Mechanical controls use centrifugal weights to close or open the inflow of water for the hydro turbines (fig.1).

\section{MODELLING OF HYBRID SYSTEM}

In order to perform MPPT (Maximum Power Point Tracking) of a small hydroelectric power station, it is necessary to drive the water turbine at an optimal speed (see preceding paragraph). For that purpose, a speed sensor gives the information. A gearbox adapts the low speed of the turbine to the speed of the machine. In the case of the production by hydraulic turbines (3), the Doubly Fed Induction Generator (DFIG) allows to optimize the produced power. Indeed, considering the variable speed and flow of tropical rivers, the Doubly Fed Induction Generator (DFIG), compensates these variations in acceptable proportions while guaranteeing a good quality of the electrical network. The strategy of operation and control consists in providing constant voltage $\mathrm{V}$ and frequency $\mathrm{f}$ and this, in spite of the speed variations and reasonable power consumption variations. Moreover, hybridization on a DC bus by a photovoltaic system brings the magnetizing of the machine $(\mathrm{V}, \mathrm{f}$ regulation). Photovoltaic system may also contribute to active and reactive power regulation.

Simulation results are obtained thanks to the scientific Matlab/Simulink ${ }^{\mathrm{TM}}$ software.

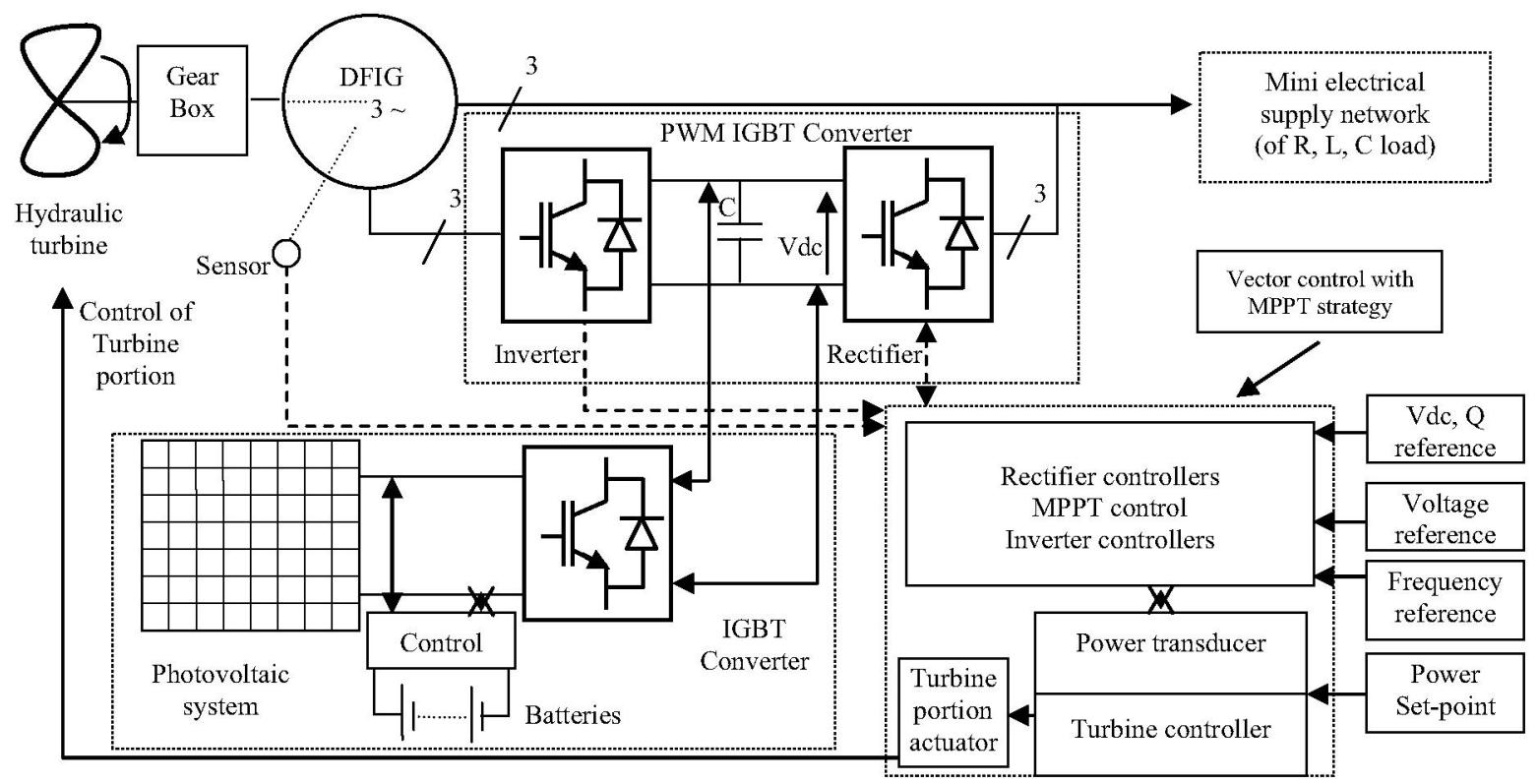

Fig.3: Asynchronous machine with wound rotor used as generator linked with a photovoltaic system on a DC Bus. 


\section{a) General diagram}

The Doubly Fed Induction Generator (DFIG) will be used in stand alone operation. In this configuration, a PWM converter with IGBT controls currents in the rotor. Moreover, the originality of this system is conferred by hybridization on a Bus DC of an already existing photovoltaic system (as indicated in fig. 3 below) which will make it possible to ensure the magnetizing of the machine.

The system is composed of a three-phase asynchronous machine with wound rotor actuated at variable speed $(+/-30 \%$ compared to rated speed) like a traditional generator and of a converter feeding the rotor which at any moment provides the complement of frequency necessary to maintain constant the frequency on the stator.

\section{b) Modelling of the machine}

- Dynamic model of the doubly fed induction generator

A commonly used model for the Doubly Fed Generator is the Park model (with the assumptions of using). Indeed, under these conditions, the asynchronous machine can be described by a differential equations system in d, q components; $\theta_{\mathrm{k}}$ is an unspecified angle with fixed axes related to the stator as indicated in fig.4.

Thus, the equations of the machine are:

$\underline{\mathrm{V}}_{\mathrm{s}}{ }^{\mathrm{k}}=\mathrm{R}_{\mathrm{s}} \underline{\mathrm{I}}_{\mathrm{s}}{ }^{\mathrm{k}}+\frac{\mathrm{d} \underline{\Phi}_{\mathrm{s}}{ }^{\mathrm{k}}}{\mathrm{dt}}+\mathrm{j} \omega_{\mathrm{k}} \underline{\Phi}_{\mathrm{s}}{ }^{\mathrm{k}}$

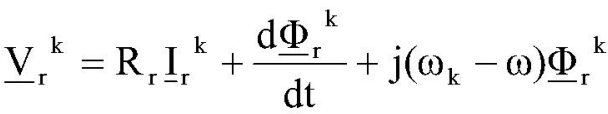

with: $\omega_{\mathrm{k}}=\frac{\mathrm{d} \theta_{\mathrm{k}}}{\mathrm{dt}}$ angular velocity of the axes system $(d, q)$ and $\omega$ angular velocity of the rotor compared to the stator; $R_{s}$ and $R_{r}$ are respectively the stator and rotor resistance.

Equations of flux are:

$$
\begin{aligned}
& \underline{\Phi}_{s}{ }^{k}=\mathrm{L}_{\mathrm{s}} \underline{\mathrm{I}}_{\mathrm{s}}{ }^{\mathrm{k}}+\mathrm{MI}_{\mathrm{r}}{ }^{\mathrm{k}} \\
& \underline{\Phi}_{\mathrm{r}}{ }^{\mathrm{k}}=\mathrm{L}_{\mathrm{r} \underline{\mathrm{I}}_{\mathrm{r}}}{ }^{\mathrm{k}}+\mathrm{MI}_{\mathrm{s}}{ }^{\mathrm{k}}
\end{aligned}
$$

$\mathrm{L}_{\mathrm{s}}$ : stator cyclic inductance; $\mathrm{L}_{\mathrm{r}}$ : rotor cyclic inductance; M: cyclic mutual inductance

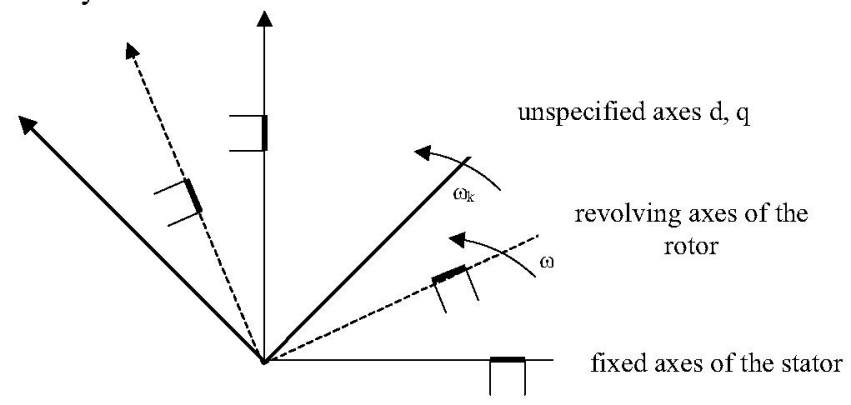

In order to simplify the equations of the DFIG, the choice of the reference frame where equations (2) and (3) are projected, must be judicious. Indeed, the majority of the authors chooses a reference frame related to the stator field. However, this choice is not the best in the considered application; the parameters to be controlled being the stator voltages, the choice of axes shifted $90^{\circ}$ behind on the vector of stator voltage $\left(\mathrm{V}_{\mathrm{sd}}=0\right.$ and $\mathrm{V}_{\mathrm{sq}}=$ $\mathrm{V}_{\mathrm{s}}$ ) is much more advantageous [7]. It allows connecting the axis system directly to the frequency of the created network. Fig.5 illustrates this choice.

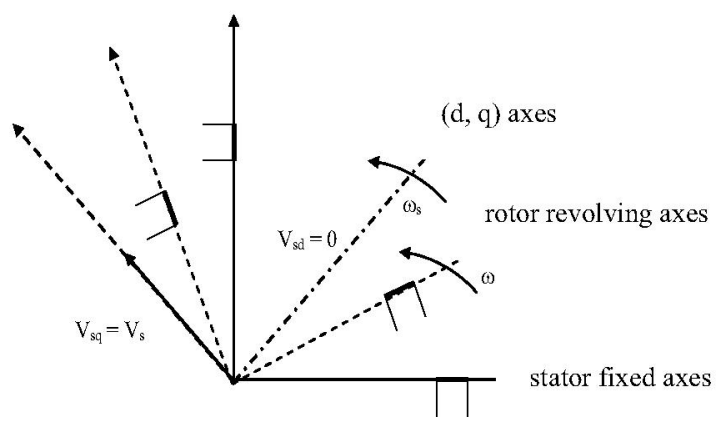

Fig.5: Reference frame choice $(\mathrm{d}, \mathrm{q})$

Under these conditions the generator equations are:

$$
\begin{array}{r}
\underline{\mathrm{V}}_{\mathrm{s}}=\mathrm{R}_{\mathrm{s}} \underline{\mathrm{I}}_{\mathrm{s}}+\frac{\mathrm{d} \underline{\Phi}_{\mathrm{s}}}{\mathrm{dt}}+\mathrm{j} \omega_{\mathrm{s}} \underline{\Phi}_{\mathrm{s}} \\
\underline{\mathrm{V}}_{\mathrm{r}}=\mathrm{R}_{\mathrm{r} \underline{\mathrm{I}}_{\mathrm{r}}}+\frac{\mathrm{d} \underline{\Phi}_{\mathrm{r}}}{\mathrm{dt}}+\mathrm{j} \omega_{\mathrm{r}} \underline{\Phi}_{\mathrm{r}} \\
\text { and } \quad \underline{\Phi}_{\mathrm{s}}=\mathrm{L}_{\mathrm{s}} \underline{\mathrm{I}}_{\mathrm{s}}+\mathrm{MI} \underline{\mathrm{I}}_{\mathrm{r}} \\
\underline{\Phi}_{\mathrm{r}}=\mathrm{L}_{\mathrm{r}} \underline{\mathrm{I}}_{\mathrm{r}}+\mathrm{MI} \underline{\mathrm{s}}_{\mathrm{s}}
\end{array}
$$

By projecting these equations on the $(\mathrm{d}, \mathrm{q})$ axes system, the equations become:

$$
\begin{aligned}
& \mathrm{V}_{\mathrm{sd}}=\mathrm{R}_{\mathrm{s}} \mathrm{I}_{\mathrm{sd}}+\frac{\mathrm{d} \Phi_{\mathrm{sd}}}{\mathrm{dt}}-\omega_{\mathrm{s}} \Phi_{\mathrm{sq}} \\
& \mathrm{V}_{\mathrm{sq}}=\mathrm{R}_{\mathrm{s}} \mathrm{I}_{\mathrm{sq}}+\frac{\mathrm{d} \Phi_{\mathrm{sq}}}{\mathrm{dt}}+\omega_{\mathrm{s}} \Phi_{\mathrm{sd}} \\
& \mathrm{V}_{\mathrm{rd}}=\mathrm{R}_{\mathrm{r}} \mathrm{I}_{\mathrm{rd}}+\frac{\mathrm{d} \Phi_{\mathrm{rd}}}{\mathrm{dt}}-\omega_{\mathrm{r}} \Phi_{\mathrm{rq}} \\
& \mathrm{V}_{\mathrm{rq}}=\mathrm{R}_{\mathrm{r}} \mathrm{I}_{\mathrm{rq}}+\frac{\mathrm{d} \Phi_{\mathrm{rq}}}{\mathrm{dt}}+\omega_{\mathrm{r}} \Phi_{\mathrm{rd}}
\end{aligned}
$$

The equations of magnetic fluxes become:

$$
\left\{\begin{array}{l}
\Phi_{\mathrm{sd}}=\mathrm{L}_{\mathrm{s}} \mathrm{I}_{\mathrm{sd}}+M \mathrm{I}_{\mathrm{rd}} \\
\Phi_{\mathrm{sq}}=\mathrm{L}_{\mathrm{s}} \mathrm{I}_{\mathrm{sq}}+M \mathrm{I}_{\mathrm{rq}} \\
\Phi_{\mathrm{rd}}=\mathrm{L}_{\mathrm{r}} \mathrm{I}_{\mathrm{rd}}+\mathrm{MI}_{\mathrm{sd}} \\
\Phi_{\mathrm{rq}}=\mathrm{L}_{\mathrm{r}} \mathrm{I}_{\mathrm{rq}}+M \mathrm{I}_{\mathrm{sq}}
\end{array}\right.
$$




\section{VECTOR CONTROL STRATEGY}

Due to the multidisciplinary of the proposed approach, the adopted methodology for modelling is to structure the investigations fields by collaborations requiring specific competences (fig. 6 hereafter).

The investigations of hydraulic specialists concentrate their efforts on the characterization of the river and the turbine whereas electric engineering specialists are involved with the control of the stand alone generator $(\mathrm{V}$, $f$ regulation). 3 cases of operation are considered: hyposynchronous operation, operation at synchronism speed and hyper-synchronous operation. Starting with magnetizing from the photovoltaic system needs a special and original approach.

The Matlab/Simulink simulation scheme proposed on fig. 6 , is broken up into 6 modules: from left on the right:

- characterization of the river,

- turbine characteristic (which is reproduced by a D.C current machine with MPPT control),

- generating hybridization on D.C bus through photovoltaic system,

- MPPT control of the converter unit with the generator (characteristics: $3 \mathrm{KW}-380 \mathrm{~V}-50 \mathrm{~Hz}$ )

- connection to the network

- characteristics of a typical consumers load (R, L, $\mathrm{C}$ load with the network)

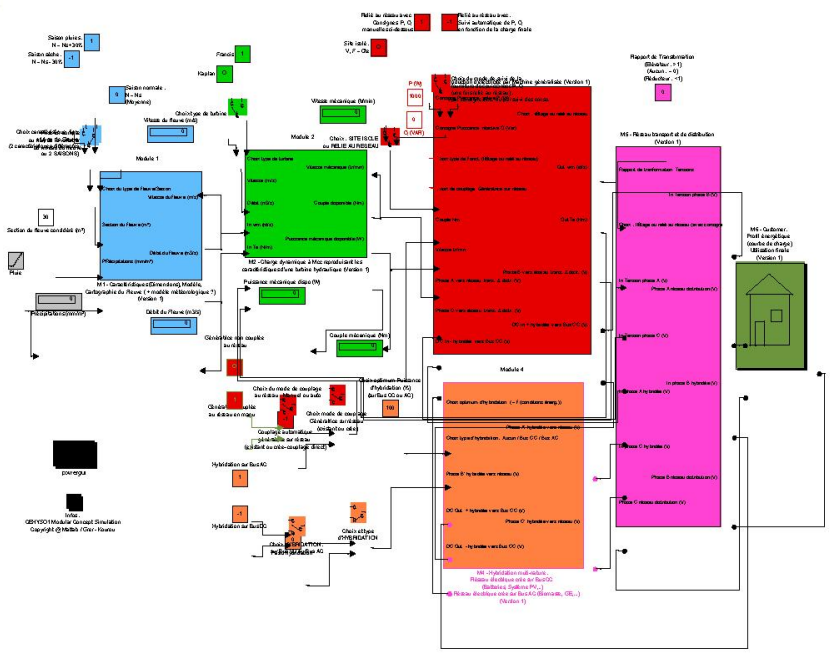

Fig.6: Modular strategy of suggested simulation

\section{V.SIMULATION RESULTS}

Simulations (fig.7) have been carried out over 100 seconds (near the synchronism speed). We can observe the stability of the voltage and the frequency and this, in spite of transients reproducing a degraded operation

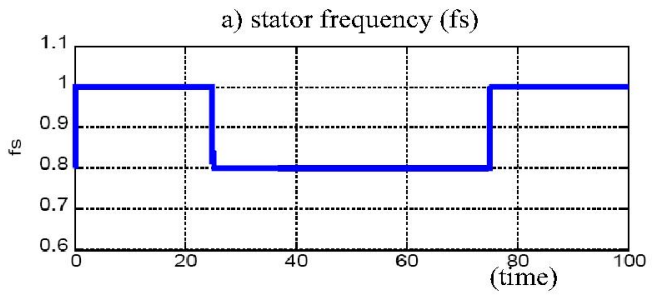

b) rotor frequency (fr)

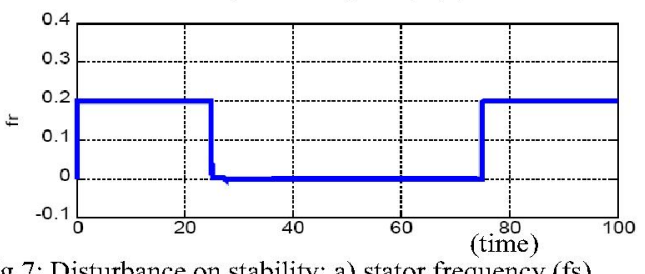

Fig. 7: Disturbance on stability: a) stator frequency (fs), b) rotor frequency (fr)

Simulations (fig.9, fig.10) have been carried out over 4 seconds (starting system). We can observe the stability of the stator and rotor frequencies and this, after starting.

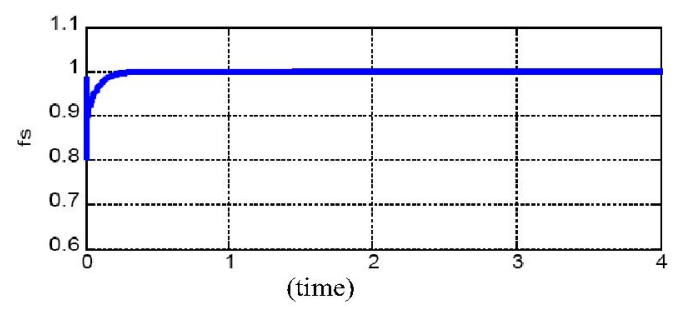

Fig.9: Stability of stator frequency after starting

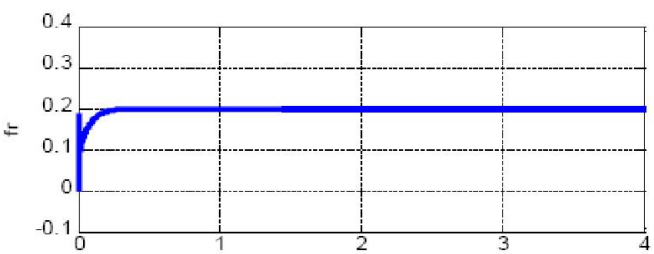

Fig. 10: Stability of rotor frequency after starting

Simulations (fig.11, fig.12) have been carried out over 50 seconds (starting system). We can observe the stability of the voltage and the frequency and this, after starting. 


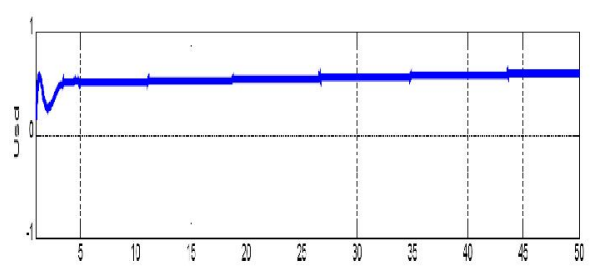

Fig. 11: Stator Voltage of d axes (vsd in p.u.) after starting

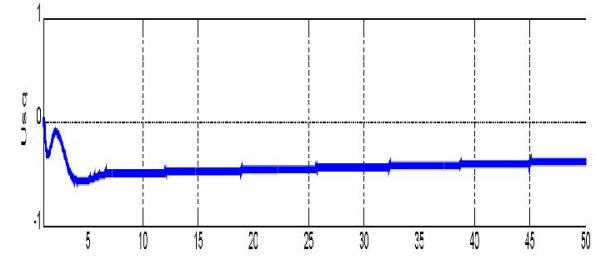

Fig. 12: Stator Voltage of q axes (vsq in p.u.) after starting

Simulations (fig.13) have been carried out over 25 seconds (starting system). We can observe the stability of the voltage and the frequency and this, in spite after starting.

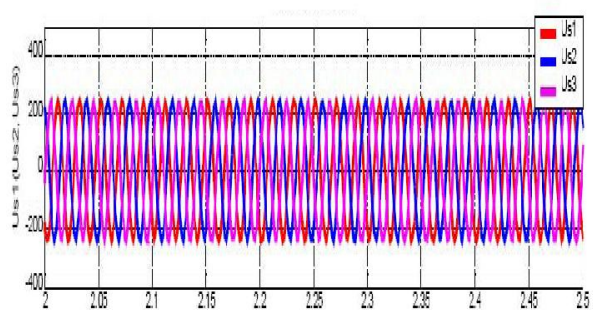

Fig.13: Stator Voltage after starting

\section{CONCLUSION}

Thus, due to the large speed and flow variations in the French Guiana rivers, the Doubly Fed Induction Generator (DFIG), presents an original solution of compensation in acceptable proportions of the variability of the primary source and thus guarantees a good quality of the produced energy. Energy for magnetizing is furnished by photovoltaic cells through a DC Bus.

Simulations show that this type of system used in a Micro-Hydro Power Station is recommended for weak height falls. A complete $10 \mathrm{~kW}$ test bench controlled by a DSPACE system will allow validating the proposed concept. Stability and performances have to be carried on

Further developments will be the study of various control devices towards the interconnection and hybridization possibilities with other electricity power systems production with strong variability, (i.e. for isolated sites in equatorial environment and a mini network).

\section{VII.ACKNOWLEDGMENT}

This multidisciplinary research subject appears in the $6^{\text {th }}$ measure of CPER-DocUp 2000-2006. Scientifically validated by the French Ministry for Research and Technology; this project is granted by European structural funds (FEDER), grants from the French Guiana Area, the Government and the University of the French West Indies and French Guiana.

\section{REFERENCES}

[1]. Pr. C.A. Mockmore, Pr. F.Merryfield : «The Banki Water Turbine 》, Oregon State College, Bulletin Series No.25 - Feb. 1949

[2]. MVA.Nunes, JA.Peças Lopes, HH.Zürn, UH.Bezerra, RG.Almeira: "Influence of the Variable Speed Wind Generators in Transcient Stability Margin of the Conventional Generators Integrated in Electrical Grids"-IEEE transactions on Energy Conversion, Vol 19, No4, Dec 2004

[3]. Water Power Industries «Energy from quietly flowing rivers », p7, CADDET Info Point, Issue 1/4, March 2004

[4]. SERT for ADEME (French Guiana) «Etude de l'électrification du campement touristique de Saut Sonnelle », 24p, July 1999

[5]. H.Godfroid, A.Mirzaian, D.Ramuz: 'Machine synchrone pour procédés exigeants', Revue Internationale de Génie électrique, pp9-35

[6]. F.Poitiers, M.Machmoum, R.LeDoeuff: 'Simulation of a Wind Energy Conversion System Based on a Doubly Fed Induction Generator', EPE 2003, CD, pp1-10

[7]. S.Tnani, S.Diop, A.Berthon, JM.Kauffmann: 'A generalized Model for Double Fed Induction Machines', IASTED 1995

[8]. F.Khatounian, E.Monmasson, F.Berthereau, E.Delaleau, JP Louis: 'Analyse et commande d'un système de génération électrique pour réseau de bord d'avion', EF 2003 - Supélec, 9, 10 Déc. 2003, CD

[9]. D.Lecocq, P.Lataire, W.Wyjmeersch : 'The Double Fed Induction Motor both Stator and Rotor Voltages Controlled by Cycloconverters', European Power Electronics Journal, Vol 1, Oct 1991, pp 103-112

[10]. S. Muller, M. Deicke, R.W. De Doncker : 'Doubly-Fed Induction Generators Systems for Wind Turbines, IEEE Industry Applications Magazine, May, June 2000

[11]. B. Robyns, Y. Pankow, L. Leclercq, B. François : 'Equivalent Continuous Dynamic Model of Renewable Energy Systems', 7th International Conference on Modeling and Simulation of Electric Machines, Converters and Systems : ELECTRIMACS 2002, Canada, Montreal, CD

[12]. Ludovic Leclercq, Aymeric Ansel, Benoït Robyns : "Autonomous high power variable speed wind generator system" : EPE 2003 Toulouse CD-Rom

[13]. O.Gergaud, G.Robin, B.Multon, H.Ben Ahmed : "Energy modeling of a lead acid battery within hybrid Wind / Photovoltaic systems" : EPE 2003 - Toulouse CD-Rom

[14]. Christian R Kelber, Walter Schumacher : "Active damping of flux oscillations in doubly-fed AC machines using dynamic variation of the system's structure" : EPE 2001 - Graz CD-Rom

[15]. D.Ramuz, M.Camara, M.Sébéloué, O.Tamarin, F.Roubaud, H.Clergeot, JM.Kauffman : "Modelling and Simulation of a Doubly Fed Induction Generator in stand alone Variable speed hydro Turbine" : EPE 2005 - Dresden (RFA) - Paper 964 - CD ROM 